\title{
CSF Lactate Dehydrogenase Activity in Patients with Creutzfeldt-Jakob Disease Exceeds That in Other Dementias
}

\author{
H. Schmidt ${ }^{a} \quad$ M. Otto ${ }^{\text {a }}$ P. Niedmann ${ }^{b} \quad$ L. Cepek ${ }^{a} \quad$ A. Schröter ${ }^{c}$ \\ H.A. Kretzschmar ${ }^{d}$ S. Poser ${ }^{a}$ \\ Departments of a Neurology and ${ }^{b}$ Clinical Chemistry, University of Göttingen, Göttingen, \\ 'Department of Neurology, University of Würzburg, Würzburg, and dInstitute of Neuropathology, \\ University of Munich, Munich, Germany
}

\section{Key Words}

Lactate dehydrogenase $\cdot$ Creutzfeldt-Jakob disease . Dementia - 14-3-3 protein - Tau protein - Alzheimer disease

\begin{abstract}
The diagnosis of Creutzfeldt-Jakob disease (CJD) is still made by exclusion of other dementias. We now evaluated lactate dehydrogenase (LDH) in the cerebrospinal fluid (CSF) as a possible additional diagnostic tool. CSF LDH levels of patients with CJD $(n=26)$ were compared with those in other dementias $(n=28)$. $L D H$ isoenzymes were determined in a subset $(n=9)$. Total $L D H$ and isoenzyme LDH-1 were significantly higher, whereas the fractions of LDH-2 and LDH-3 were significantly lower in CJD patients. We conclude that in addition to established CSF parameters, LDH and its isoenzymes might serve as a further help to discriminate between CJD and other dementias.
\end{abstract}

Copyright $\odot 2004$ S. Karger AG, Basel

\section{Introduction}

Creutzfeldt-Jakob disease (CJD) is a rare transmissible disease with rapidly progressive dementia as the leading symptom. Patients usually die within less than a year after the onset of symptoms [1,2]. A definite diagnosis of CJD can only be made by neuropathological or immunochemical demonstration of the pathological isoform of the prion protein (PrPSc) in human brain tissue. Up to now, there are no reliable diagnostic tests for PrPSc in serum or cerebrospinal fluid (CSF). The ante-mortem diagnosis is made according to typical clinical symptoms [3, 4], supported by typical EEG findings [5], increased concentrations of neuron-specific enolase (NSE) [6, 7], tau protein [8] protein $14-3-3[6,9,10]$ and $S-100$ protein $[11]$ in the CSF. The latter is also elevated in serum of patients with CJD [12]. However, these markers only reflect neuronal destruction. LDH is another accepted marker for cellular damage. LDH is released by all types of cells after loss of membrane integrity. CSF-LDH activity is increased in central nervous system (CNS) infections [13, 14], head trauma [15, 16], vascular accidents [17], intracerebral lymphoma [18], organophosphate poisoning [19], and metastatic CNS disease [20]. However, LDH has not been investigated, yet in CJD.

\section{Methods}

Patients

We investigated CSF samples of 54 patients. All patients with suspected CJD were initially evaluated clinically [12]. Twenty-six patients were classified as having CJD by standard clinical criteria [ 4 , $21,22]$, the remaining 28 patients suffered from other dementias.

\begin{tabular}{ll}
\hline KARGER & ( ) 2004 S. Karger AG, Basel \\
1420-8008/04/0173-0204\$21.00/0 \\
$\begin{array}{l}\text { Fax +4161306 12 34 } \\
\text { E-Mail karger@karger.ch } \\
\text { www.karger.com }\end{array}$ & $\begin{array}{l}\text { Accessible online at: } \\
\text { www.karger.com/dem }\end{array}$
\end{tabular}

Dr. med. H. Schmidt

Department of Neurology, University of Göttingen

Robert-Koch Strasse 40

DE-37075 Göttingen (Germany)

Tel. +49 551 398484, Fax +49551 398405, E-Mail hschmid2@gwdg.de 
Fig. 1. a Total CSF activity of LDH in patients with CJD dementia $(n=26)$ and non-CJD dementia $(n=28)$; CSF LDH of patients negative for 14-3-3 protein $(n=3)$ are marked as dots. b LDH isoenzymes in patients with CJD dementia and nonCJD dementia. Median, 25th/75th percentile (box), 5th/95th percentile (whisker cap); $\mathrm{n}=9$ in each group.

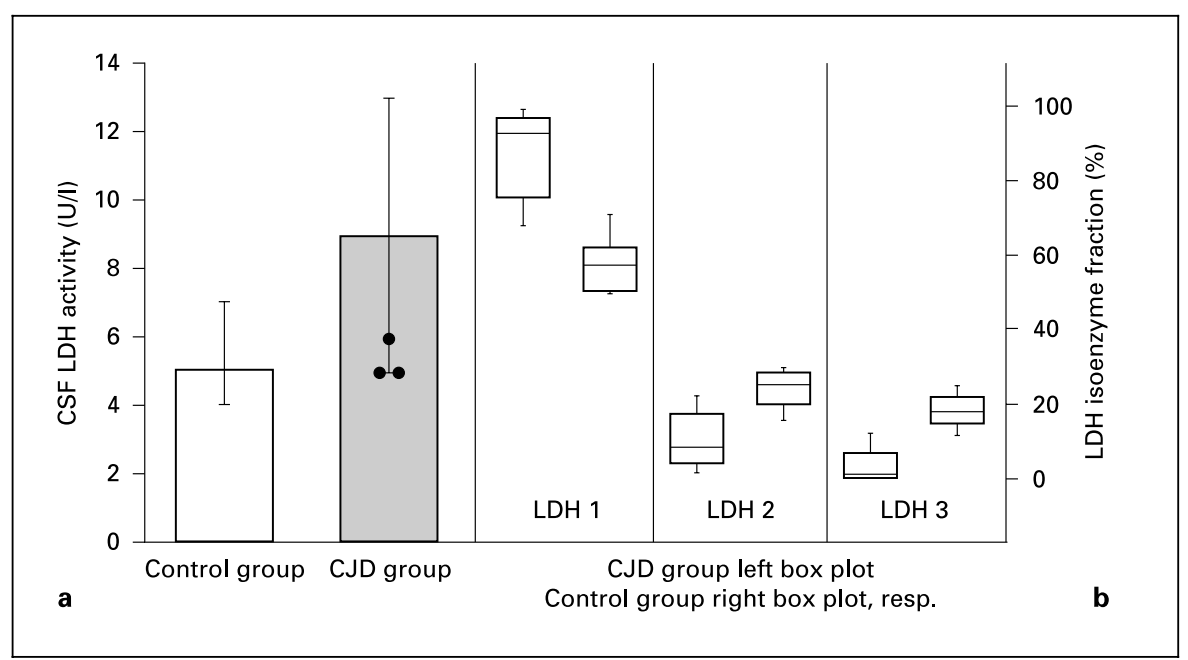

The male-to-female ratio of patients with CJD was $4 / 22$, their age was $65.0 \pm 10.7$ years (mean \pm standard deviation).

Twenty-three of 26 CJD patients were positive for the 14-3-3 protein in the CSF, in 23 of $26 \mathrm{CJD}$ patients the diagnosis was confirmed neuropathologically [23]. All three 14-3-3-negative patients were among the neuropathologically confirmed cases of CJD. All CJD patients had an intact blood to CSF barrier, reflected by a normal CSF to serum albumin ratio according to Reiber [24].

\section{Other Dementias}

This group comprised 28 patients ( 11 men, 17 women; age 62.2 \pm 8.2 years, mean $\pm \mathrm{SD}$ ). The final diagnosis in these patients was made on the basis of the most recent clinical assessment according to ICD-10 or DSM-IV. The group with other dementias comprised the following diagnoses: Alzheimer's disease $(n=12)$, vascular dementia $(\mathrm{n}=4)$, dementia due to encephalitis $(\mathrm{n}=3)$, multisystem atrophy $(\mathrm{n}=2)$, Huntington's disease $(\mathrm{n}=1)$, paraneoplastic syndrome $(\mathrm{n}=$ 1), multiple sclerosis $(n=1)$, dementia of unknown origin $(n=4)$.

The study was approved by the local ethics committee in Göttingen.

\section{LDH Measurement}

The total LDH activity was measured enzymatically according to McKenzie and Henderson [25] in all patients. In 9 patients with CJD and 9 with other dementias CSF LDH isoenzymes were also measured: CSF had to be concentrated five- to tenfold by ultracentrifugation (Centrifree-System ${ }^{\circledR}$, Millipore, Inc., USA). Afterwards, the concentrated CSF was mounted onto agarose gel and separated electrophoretically. A substrate-specific staining of the different fractions of LDH was performed by addition of lactate and NAD yielding $\mathrm{NADH}$ which in turn was allowed to react with $p$-nitroblue tetrazolium chloride (NBT) and phenazine methosulfate. This step results in oxidation of NADH to NAD and the formation of an NB-formazan dye which reveals isoenzyme bands. The isoenzyme bands were quantitated by scanning densitometry at a wavelength of $600 \mathrm{~nm}$. The test procedure was performed with a commercial electrophoresis system (LD-Paragon ${ }^{\circledR}$, Beckman Inc., USA).

CSF-LDH in Creutzfeldt-Jakob Disease

\section{Statistical Analysis}

As the results of the CJD and non-CJD groups did not follow a Gaussian distribution, calculations of median (25/75th percentile) and significances calculated with Mann-Whitney U test are given. We obtained a cut-off value using the Youden Index [26], though the limited number of patients does not allow its clinical use.

\section{Results}

CSF LDH activity was significantly higher in CJD patients (mean 9, range 5-13 U/1) than in the non-CJD group (mean 5, range 4-7 U/1; $\mathrm{p}=0.007$ ). The levels of LDH in 14-3-3-protein-negative CJD patients $(n=3)$ ranked among the lowest in the CJD group (fig. 1).

The best cut-off value was $8 \mathrm{U} / 1$, yielding a sensitivity of $69 \%$, a specificy of $84 \%$ (Youden Index 0.53 ). Isoenzymes LDH-1, LDH-2 and LDH-3 could be detected, fractions of LDH-4 and LDH-5 were usually below the detection limit.

The percentage of isoenzyme fractions differed significantly: LDH-1 was higher in CJD patients (median 92\%; 25 th $/ 75$ th percentile $75 / 96 \%$ vs. $57 \% ; 50 / 61 \% ; p=0.001$ ), while both LDH-2 (8\%; $4 / 16 \%$ vs. $25 \% ; 21 / 28 \%$; p = $0.003)$ and LDH-3 (1\%;0/9\% vs. $18 \% ; 15 / 21 \% ; p=$ $0.001)$ were lower as compared with the control group.

\section{Discussion}

$\mathrm{LDH}$ release in the CSF occurs in various conditions of acute brain cell damage. Even though CJD has a subacute clinical course, the results show that the death rate of 
brain cells is still important enough to cause a higher release of LDH into the CSF than in dementia of other origins.

Since LDH-1 is the predominant brain LDH isoenzyme [20], the increased proportion of this isoenzyme and the increased total CSF LDH activity reflect the CJDinduced brain damage well.

Three of the CJD patients were negative for 14-3-3 protein. Their $\mathrm{LDH}$ activities were distinctly lower than the median value of all CJD patients. Hence, the absence of the scaffolding protein 14-3-3 in CSF might be a sign of comparatively conserved cellular integrity in 14-3-3-negative CJD patients.

Our calculated cut-off value doubtless needs to be interpreted with caution because of the small number of investigated patients. However, it is already evident that its differential diagnostic test is as good as that of other markers, such as 14-3-3, tau protein or S-100B.

We conclude that CSF analysis of total LDH activity and its subfractions can help in the differential diagnosis of CJD in a cost-effective manner. Patients lacking 14-3-3 in the CSF might have attenuated brain cell damage as compared with those CJD patients who are positive for this protein.

\section{Acknowledgement}

The authors thank the physicians who provided data on suspect cases to the German CJD consultatory laboratory. This study was in part supported by a grant from the Federal Ministry of Health (BMG) and Federal Ministry of Science and Technology (BMBF).

\section{References}

1 Brown P, Gibbs CJJ, Rodgers-Johnson P, Asher DM, Sulima MP, Bacote A: Human spongiform encephalopathy: The National Institute of Health series of 300 cases of experimentally transmitted disease. Ann Neurol 1994;35:513529.

2 Geldmacher DS, Whitehouse PJ: Differential diagnosis of Alzheimer's disease. Neurology 1997;48:2-9.

3 Will RG, Zeidler M, Brown P, Harrington M, Lee KH, Kenney KL: Cerebrospinal-fluid test for new variant Creutzfeldt-Jakob disease. Lancet 1996;348:955.

4 Masters CL, Harris JO, Gajdusek DC, Gibbs CJJ, Bernoulli C, Asher DM: Creutzfeldt-Jakob disease: Patterns of worldwide occurrence and the significance of familial and sporadic clustering. Ann Neurol 1979;5:177-188.

5 Steinhoff BJ: EEG features of CreutzfeldtJakob disease and their differential diagnosis. Adv Clin Neurosci 1998:8:199-211.

6 Beaudry P, Cohen P, Brandel JP, Delasnerie Laupetre N, Richard S, Launay JM, Laplanche JL: 14-3-3 protein, neuron-specific enolase, and S-100 protein in cerebrospinal fluid of patients with Creutzfeldt-Jakob disease. Dement Geriatr Cogn Disord 1999;10:40-46.

7 Jimi T, Wakayama Y, Shibuya S, Nakata H, Tomaru T, Takahashi Y: High levels of nervous system-specific proteins in cerebrospinal fluid in patients with early stage CreutzfeldtJakob disease. Clin Chim Acta 1992;211:3746.
8 Otto M, Wiltfang J, Cepek L, Neumann M, Mollenhauer B, Steinacker P, Ciesielczyk B, Schulz-Schaeffer W, Kretzschmar HA, Poser S: Tau protein and 14-3-3 protein in the differential diagnosis of Creutzfeldt-Jakob disease. Neurology 2002;58:192-197.

9 Zerr I, Bodemer M, Gefeller O: Detection of 14-3-3 protein in the cerebrospinal fluid supports the diagnosis of Creutzfeldt-Jakob disease. Ann Neurol 1998;43:32-40.

10 Hsich G, Kenney K, Gibbs CJ, Lee KH, Harrington MG: The 14-3-3 brain protein in cerebrospinal fluid as a marker for transmissible spongiform encephalopathies. N Engl J Med 1996;335:924-930.

11 Otto M, Stein H, Szudra A: S-100 protein concentration in the cerebrospinal fluid of patients with Creutzfeldt-Jakob disease. J Neurol 1997; 244:566-570.

12 Otto M, Wiltfang J, Schutz E: Diagnosis of Creutzfeldt-Jakob disease by measurement of S100 protein in serum: Prospective case-control study. Br Med J 1998;316:577-582.

13 Murphy EJ, Horrocks LA: Enzymatic changes in the cerebrospinal fluid in patients with infections of the central nervous system. Acta Paediatr 1994;83:1146-1150.

14 Sher PK, Hu S: GABA accumulating neurons are relatively resistant to chronic hypoxia in vitro: An auroradiographic study. Brain Res Bull 1990;25:697-701.

15 Levy G, Rivals A, Bertando J, François G: Do enzyme determinations have any prognostic value in neurotraumatology? Ann Anesth Fr 1976;17:1279-1284.

16 Rao CJ, Shukla PK, Mohanty S, Reddy YJ: Predictive value of serum lactate dehydrogenase in head injury. J Neurol Neurosurg Psychiatry 1978;41:948-953.
17 Donnan GA, Zapf P, Doyle AE, Bladin PF: CSF enzymes in lacunar and cortical stroke. Stroke 1983;14:266-269.

18 Stewart DJ, Keating MJ, McCredie KB: Natural history of central nervous system acute leukemia in adults. Cancer 1981;47:184-196.

19 Kolesnichenko IP, Dolgo-Saburova IS, Somova TV: Changes in the biochemical composition of the cerebrospinal fluid in acute carbophos poisoning. Zh Nevropatol Psikhiatr 1992; 92:95-99.

20 Subash MN, Rao BS, Shankar SK: Changes in lactate dehydrogenase isoenzyme pattern in patients with tumors of the central nervous system. Neurochem Int 1993;22:121-124.

21 WHO: Consensus on criteria for sporadic CJD. Geneva: http://www.who.int/emc-documents/ tse/docs/whoemczdi989.pdf, 1998.

22 Will RG: Epidemiology of Creutzfeldt-Jakob disease. Br Med Bull 1993;49:960-970.

23 Kretzschmar HA, Ironside JW, DeArmonde SJ, Tateishi J: Diagnostic criteria for sporadic Creutzfeldt-Jakob disease. Arch Neurol 1996; 53:913-920.

24 Reiber HO: External quality assessment in clinical neurochemistry: Survey of analysis for cerebrospinal fluid (CSF) proteins based on CSF/serum quotients. Clin Chem 1995;41: 256-263.

25 McKenzie D, Henderson AR: Electrophoresis of lactate dehydrogenase isoenzymes. Clin Chem 1983;29:189-195.

26 Youden WJ: Index rating for diagnostic tests. Cancer 1950;3:32-35. 